\title{
Historic Sites in Council Bluffs
}

Dorothy Schwieder

The following short article was one of a series on Iowa history prepared by Mrs. Schwieder and presented as part of her five-minute radio program, "Assignment," which can be heard twice daily on woI AM and FM Ames at 8:55 in the morning and 5:40 in the afternoon. Her source material included the following: The Historic General Dodge House, a brochure published by the Council Bluffs Park Commission (no date), and Grenville M. Dodge: Soldier, Politician, Railroad Pioneer, by Stanley P. Hirshson (Bloomington: Indiana University Press, 1967). The rest of the material was gathered from private interviews with employees of the Dodge House and the Pottawattamie County Sheriff, Mr. Wicheal.-Ed.

Every community, large or small, old or new, has some historical significance and through its institutions and past personalities offers visitors a view of its past. One such community, rich in historical sites and colorful legends, is Council Bluffs. Spawned by the Mormon trek across Iowa in the 1840s, fostered by early railroad activities and visited by dignitaries such as Abraham Lincoln in the 1850s, Council Bluffs rapidly developed into an important western Iowa railroad and commercial center.

Among the earliest settlers in that region were the Mormons. Reaching the Missouri River on June 14, 1846, they encountered a primitive settlement known as Hart's Bluff, named after the man who operated a trading post in the vicinity. The Mormons later changed the name to Kanesville in honor of Thomas L. Kane, an Army officer who helped them in their trek west. In 1853 the name was changed to Council Bluffs. The community attracted many energetic 
young men such as Grenville Dodge who helped it develop into a bustling departure point for the west. As population increased the Union Pacific located its eastern terminus there and Council Bluffs was destined to become a major commercial center in Iowa. Today it remains a busy community as well as offering many interesting spots to visit.

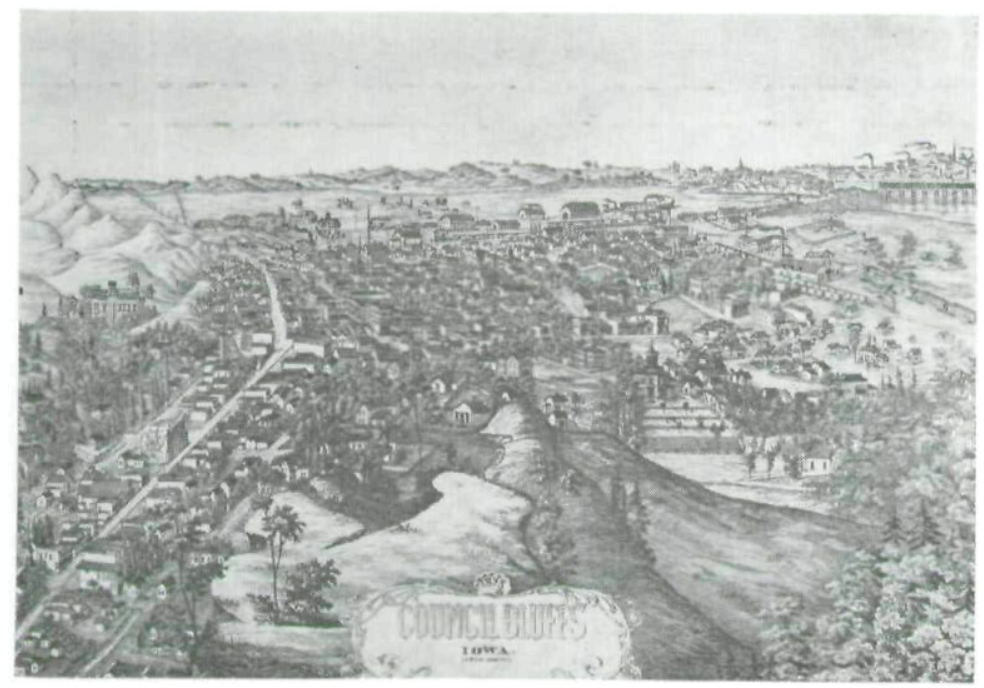

Department of History and Archives

\section{A view of Council Bluffs circa 1875.}

An appropriate starting point on a tour of the city is the General Grenville Dodge House located at 605 Third Street. Dodge, an important Nineteenth Century railroad figure, built the house in 1869 at a cost of $\$ 35,000$. The fourteen room, three story mansion was designed by William Boyington, a Chicago architect who also designed the Hubbell mansion in Des Moines. Containing double parlors, a library, a conservatory, five bedrooms plus servants' quarters and a ballroom, the house is an excellent example of Nineteenth Century victorian architecture. Throughout the house Dodge insisted on the very finest building materials and appointments. Today the results of Dodge's careful planning can be seen in the beautiful black walnut woodwork, bronze door hinges with silver plates, elaborate plaster ceiling medallions, 
six marble fireplaces and gleaming parquet floors. The home was designated a National Historic Landmark in 1963 and is open to the public year round.

Today a vacant lot stands across the street from the Dodge house but several years ago a pink house stood on that spot and added a touch of local color. Council Bluffs natives relate the story of an individual who disliked Dodge so intensely that he bought a lot and built a house just to spite the General. Dodge's adversary knew that the General liked to sit in his second floor study and look out over the city's huge railroad yard. To shut off Dodge's view the man built his home directly across the street from the Dodge house. He succeeded in his intent-the General's view was blocked -and the home was appropriately referred to as the "spite house."

Dodge's wife, Ann, is remembered with a special memorial popularly referred to as the "Black Angel." Local legend has it that shortly before she died, Ann Dodge had a series of unusual dreams. Three nights before her death she dreamed that she was standing on the shores of a river when a boat approached carrying an angel. The angel said she carried a cup containing the gift of life and asked Mrs. Dodge to accept a drink. Mrs. Dodge refused. The following night the dream reoccurred and again Mrs. Dodge refused.

\section{The Dodge House}

Conrtesy of Iowa Development Commission

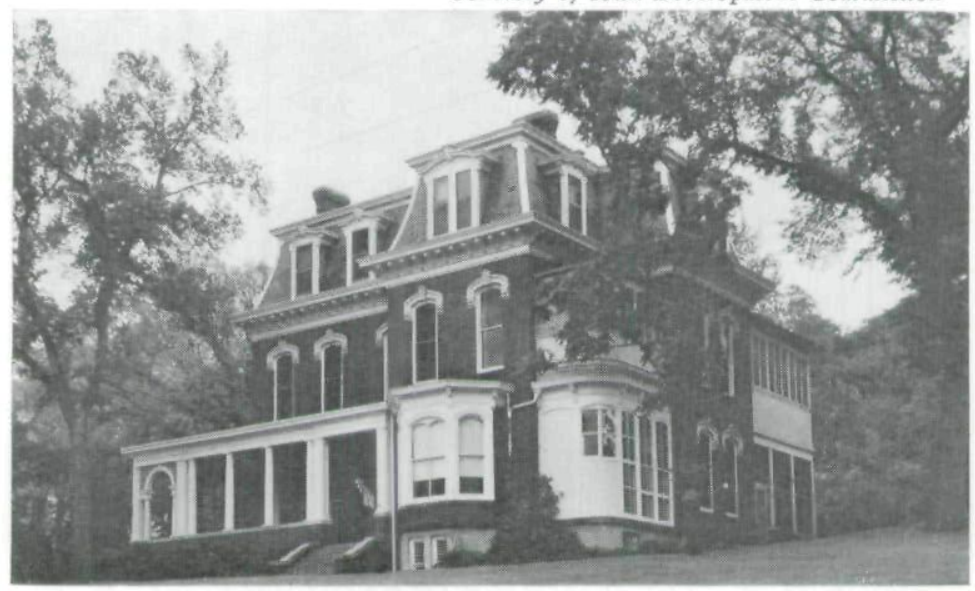


The third night Mrs. Dodge again experienced the dream, only that night she accepted the angel's request and drank from the cup of life. The next day she died. Before her death she related the dreams to her three daughters and in her memory they erected a large bronze angel. Over the years the bronze has blackened and today is appropriately referred to as the "Black Angel." The memorial is located adjacent to Fairview Cemetery.

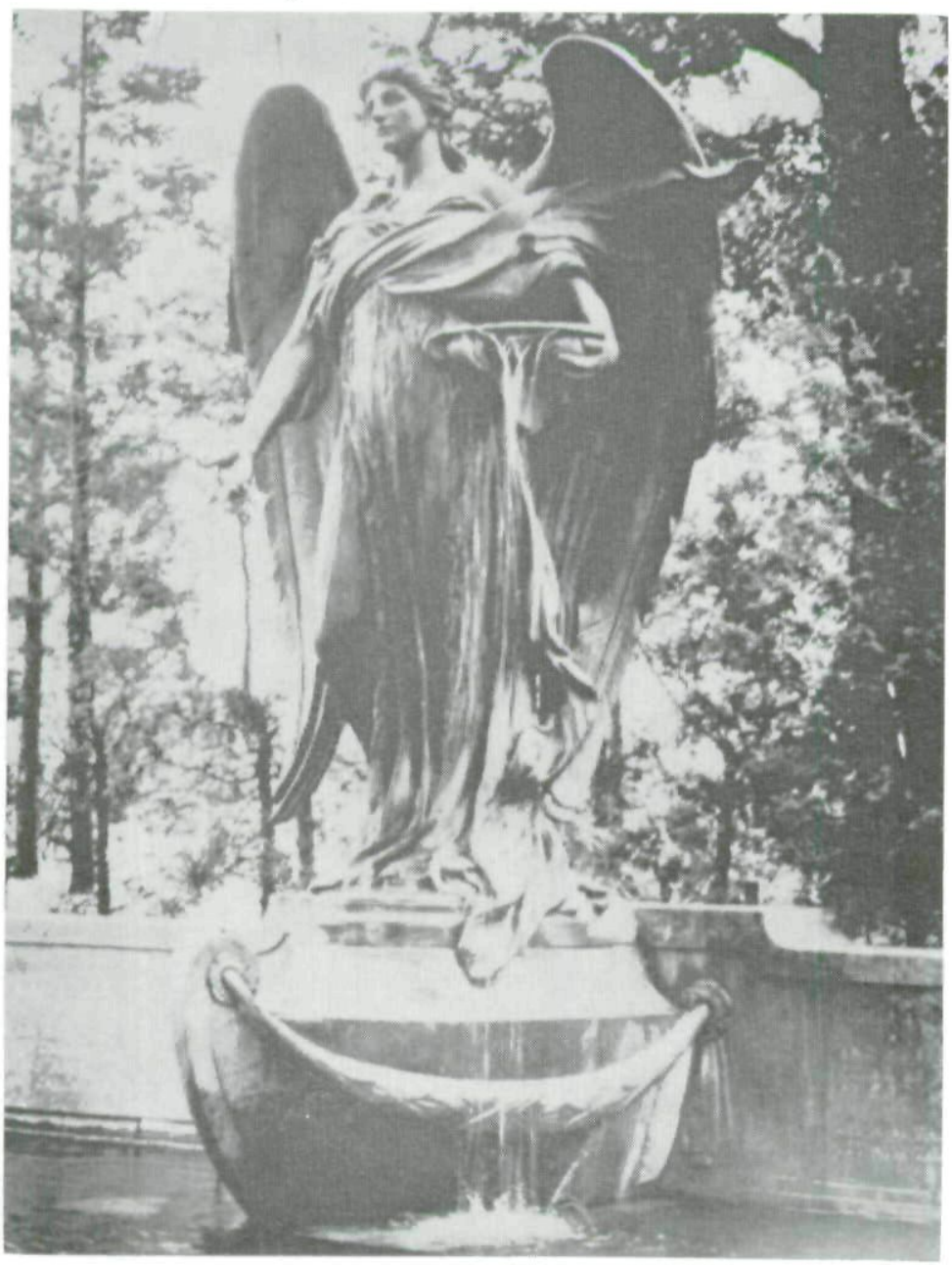

The "Black Angel" Statue 
Although the Mormons were among the first settlers, the first white visitors included Lewis and Clark, and a marker in their honor stands on a hill overlooking the city. At the time of their trip up the Missouri River the two explorers parlayed with the Otoe and Missouri Indians on the bluff above the muddy river. To record their council with the Indians on the bluffs, the two men appropriately named the area Council Bluffs and from that meeting the city took its name. The monument is situated on top of a high windswept hill giving visitors a panoramic view of both Council Bluffs and Omaha.

Pottawattamie County, in which Council Bluffs is located, also contains an unusual site- - one of the world's most unusual jails. Located at 228 Pearl Street the fascinating "Jail in the Round," or "Squirrel-type Jail" as it is sometimes called, is a three story metal drum surrounded by a gridded cage. Each story or floor has seven cells and each is pie-shaped. The only method of entering or leaving a cell is to have the drum rotated by turning a large crank. Once prisoners were placed in their cells, the jail was escape-proof. The exterior of the building is a traditional four sided structure which gives no hint of the unusual cell arrangement inside. Constructed in 1885, the jail was one of six built in the United States, but is the only one still in existence. In 1970 Pottawattamie law officials ceased to use the "Jail in the Round" for confining prisoners and today the structure is owned by the city Park Board. Eventually they hope to restore the jail to its original condition and open it to the public.

The Lincoln Monument affords visitors another scenic view of the city as well as commemorating a significant visit. The Lincoln marker lies within the city limits and records the spot where Abraham Lincoln stood overlooking the broad Missouri River Valley on his visit to western Iowa. Urged by Grenville Dodge to make Council Bluffs the division point for the Union Pacific, Lincoln agreed, and the decision brought immense economic reward to the area.

A blend of fact and fiction, a view of historical sights and colorful legends, and the contrast of a sumptuous home and an austere jail all await the visitor to Council Bluffs. 
Copyright of Annals of Iowa is the property of State of Iowa, by \& through the State Historical Society of Iowa and its content may not be copied or emailed to multiple sites or posted to a listserv without the copyright holder's express written permission. However, users may print, download, or email articles for individual use. 